\title{
STOCK MARKET INSTITUTIONAL AND REGULATORY FRAMEWORK IN THE BALTIC STATES
}

Aija Pilvere-Javorska ${ }^{1}{ }$, MBA, Irina Pilvere $^{1}$, Dr.oec. and Baiba Rivza ${ }^{1}$, Dr.hab.oec.

${ }^{1}$ Latvia University of Life Sciences and Technologies

\begin{abstract}
This paper focuses on the institutional and regulatory aspects of stock market in the Baltic States. Research aim is to assess stock market institutional and regulatory framework in the Baltic States. Analysis of the main European Union (EU) legislation acts, national laws, supervisory and market organizer rules and regulations were performed, as well as were examined European level and national level institutions, in terms of state authorities performing supervision and market organization. Authors investigated and created comprehensive structure of how stock market supervision and market organization is executed among three Baltic States, as well as constructed an extensive scheme of the main stock market impacting regulatory documents on both the (EU) and national level. Authors concluded that stock market has 2 level organization and supervision, and is most similar in Estonia and in Latvia, while in terms of national legislation stock market is more similar in Latvia and in Lithuania, with in Estonia differentiating and thus creating an advantage and being more attractive for the companies interested to be listed there.
\end{abstract}

Key words: Stock market, institutions, regulatory framework, Baltic States.

JEL code: G10, G18, G23.

\section{Introduction}

Stock market is an important place, where investors can invest their resources directly in chosen markets and companies. A. Boubakari and D. Jin (2010), states that „sometimes investors avoid investing directly to the companies because they cannot easily withdraw their money whenever they want. But through the financial stock market, they can buy and sell stocks quickly with more independence". Stock market displays positive relation to economic growth by providing new financial resources to the companies as discovered by R. Levine (1991). Some markets are riskier than others, and authors emphasize that the institutional and regulatory system can mitigate in part that risk and make some markets attractive to the issuers - the companies willing to get listed and to the investors, who are looking to invest their money by legislation and strong and established institutional system and laws. According to E. Brousseau and A. Nicita (2010) „recent debates over global financial crises have further renewed the role of institutional setting and legal standards as "genetic" features of well-performing markets". The institutional and regulatory system needs to protect investors and companies from corruption, fraud and market abuse and to set equal operation field for involved stakeholders. Researcher K. Lannoo (2001) states that „securities market regulation is to ensure proper disclosure and enforcement via a complex set of intermediaries and institutions". Accession to the EU in 2004 by Estonia, Latvia and Lithuania, changed stock market in the Baltic States, as well as its regulatory framework, where local laws are interdependent on the EU rules and regulations. A. Kein (1998) analyzed Estonian regulatory framework of securities market, and how it was formed since Estonia regained independence, and before accession to the EU, as well as analyzed institutional systems in Estonia. V. Deltuvaitè (2016), has reviewed stock market integration in the Baltic Countries and "found strong evidence that the stock markets are co-integrated" and recognized that "some empirical aspects of the Baltic stock market integration have been analyzed in the scientific literature, however, a comprehensive analysis on the Baltic stock market integration level is still missing". R. Rupeika-Apoga (2013) reviewed briefly "supervision and regulation of financial intermediaries and institutional and market infrastructure”, and „emphasizing the banking and insurance sector supervision and securities regulation”, focused on banking and insurance industries,

* Corresponding author ph : $+{ }^{37129378107 ;}$ e-mail address: apilvere@gmail.com 
the need for its improvement in the Baltic States post crisis with drawing main attention on banking industry. Importance of the institutional system, especially new one is emphasized by M.G. Hogson (1998), who states that institutions are important piece of the system. Moreover, the importance of common capital market is stressed out in the 2017 meeting among all three Baltic States Finance Ministers and the European Bank for Reconstruction and Development (EBRD) urging the need to create pan-Baltic capital market, especially „including the establishment and improvement of the underlying legal framework" (Baltic states to ..., 2017). Therefore, authors have set following research aim: to assess stock market institutional and regulatory framework in the Baltic States. In order to reach the aim, the main tasks are defined: 1) to evaluate existing stock market institutional and organizational structure in each of Baltic States; 2) to assess the main stock market impacting rules and regulations in the Baltic States from the EU and national perspective. Research object is the institutional and regulatory framework of stock market in the Baltic States. Authors believe that novelty of the research paper is that there are limited publications on stock market institutional and regulatory implications in the Baltic States, and after all three Baltic countries accessed to the euro, there is a strong need and possibility to have common capital market, but No thorough overall analysis of current legislative and institutional structure has been performed.

\section{Methodology and data.}

Authors analyzed stock market impacting legislation, market and supervisory composition in the Baltic States using following methods to fulfill research aim and tasks: analysis, synthesis, the logical construction methods, the induction and deduction methods of the EU and Baltic States stock market legislation and institutional system. Scientific literature review was performed to understand the importance and topicality of the issue. Analysis and results are based on the information as it was on January 01, 2019.

\section{Research results and discussion.}

\section{The Institutional Framework of Stock Market in the Baltic States.}

Accession to the EU in 2004 by Estonia, Latvia and Lithuania, changed the supervision format for stock market in the Baltic States. It is two level system: the EU supervisory framework, which is administered by the European Institutions such as the European Systematic Risk Board (ESRB), which is comprised of the European Commission, the European Central Bank, and the Chairs of European Securities and Markets Authority (ESMA), the European Insurance and Occupational Pensions Authority (EIOPA) and the European Banking Authority (EBA), the Joint Committee of the European Supervisory Authorities (ESAs), and the national competent or supervisory authorities of each Member State (Fig. 1). The ESRB with the ESMA caries out high-level supervision of the securities market in the EU. While 2nd level is national level supervision and market organization. Local supervision authorities oversee national securities markets. In Estonia and in Latvia, there is a separate Financial Authority formed, in Estonia, it is called the Financial Supervisory Authority (FSA), while in Latvia - the Financial and Capital Market Commission (FCMC). On contrary in Lithuania, this function is fulfilled by the Central bank - Bank of Lithuania (BoL).

Supervision framework addresses the issuers, who wants to get listed and who are already listed, and it regulates implementation and obeisance of rules and regulations, in the meantime, they do not organize the actual securities market. Stock market, is common in the Baltic States, which is true in terms of trading and settlement side of the stocks, in the meantime in each of the Baltic States, there is a separate market organizing legal entity belonging to the corporation NASDAQ (Nasdaq Tallinn AS, Nasdaq Riga, AS, AB Nasdaq Vilnius), commonly referred as to Nasdaq Baltic 
(Fig. 1). Listed companies and new issuers, who intend to get listed, must apply to the local market organizer and follow their rules for each country and local legislation, and register their securities with local securities depository, which since 2017 has merged its business and is operating in the Baltic States as Nasdaq CSD SE supervised by the FCMC, providing its services in Estonia and in Lithuania as Nasdaq CSD SE branch in Estonia and Nasdaq CSD SE branch in Lithuania. Although settlement of stocks takes place under each country's legislation. Authors conclude that despite the unite currency euro, and a talk on common capital market, the organization and supervision of stock market in the Baltic States is regulated and organized by different entities in each country.

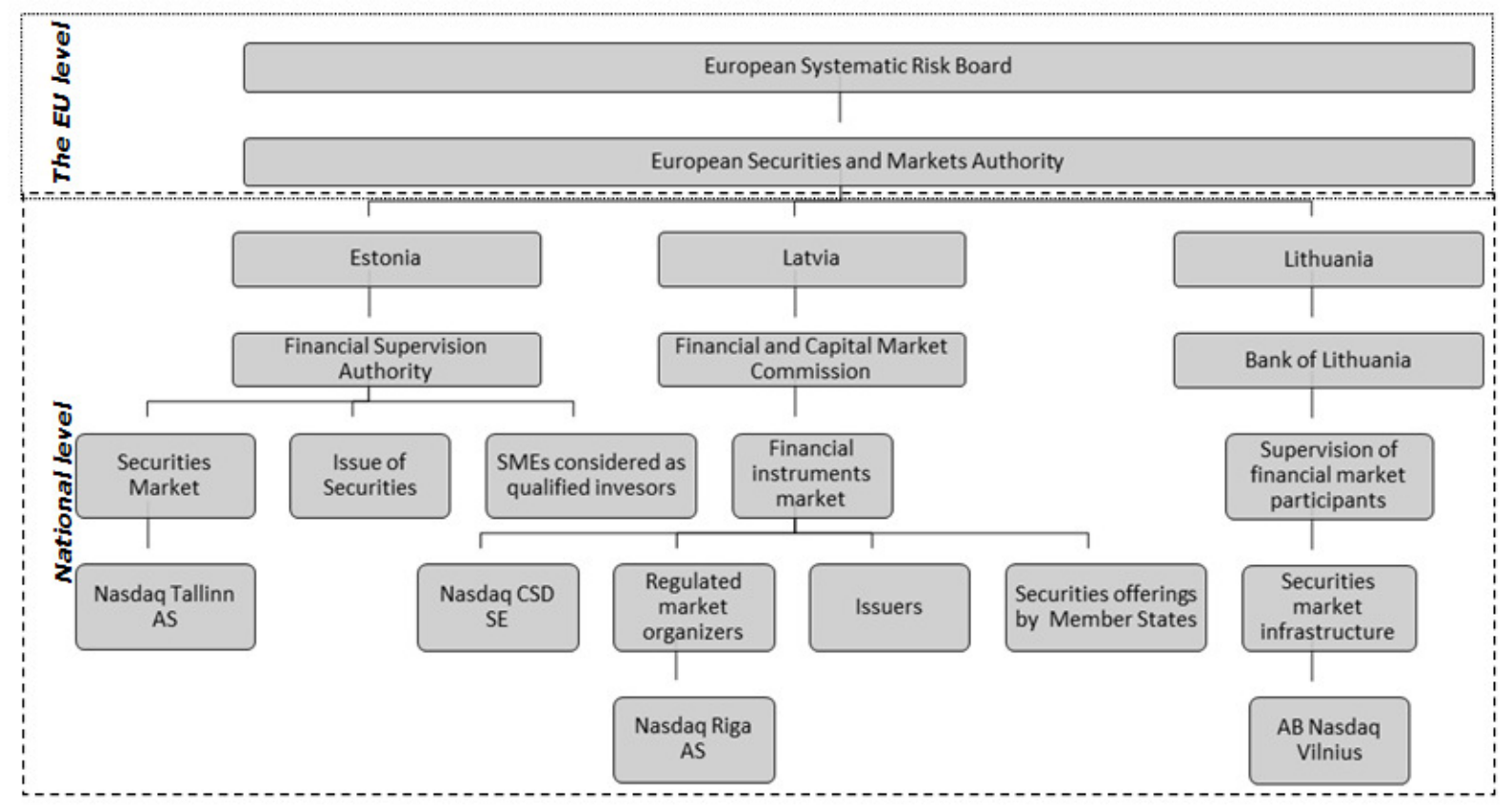

Source: Authors' constructed and derived based on ESMA, FSA, FCMC, BoL, Nasdaq Baltic, Nasdaq CSD data

Fig. 1. The Institutional System of Stock Market Supervision and Organization in the Baltic States as of 01.01.2019.

\section{Stock Market Regulatory Framework in the Baltic States.}

As stock market supervisory structure in the Baltic States is two level, that is also the case with stock market rules and regulations (Fig. 2). With the accession to the EU, there are two level rules and regulations: the EU and national level. On the EU level, authors have identified eight main impacting legislation acts, which consist of five regulations and three directives. As per the EU definition: "A "regulation" is a binding legislative act. It must be applied in its entirety across the EU", while "A "directive" is a legislative act that sets out a goal that all EU countries must achieve. However, it is up to the individual countries to devise their own laws on how to reach these goals." Directives are implemented in the local legislation as per each Member States, how it sees it fit. Thus, there might be a difference in the interpretation and application of the requirements set out in the directives. In the meantime - regulations must be taken and applied as is, without interpretation by each Member State.

The EU legislation. The main EU regulations, which are in force and are applied on national level are: 1) Prospectus regulation No. 2017/1129 with aim to harmonize and set uniform requirements across EU and attract more diverse source of capital to the issuers; 2) Benchmark regulation No. $2016 / 2011$. It sets rules applicable to benchmark administrators and its target is to properly manage and calculate performance for index/funds; 3) Regulation No. 600/2014 or Markets in Financial Instruments Regulation (MiFIR), which targets to protect not only investors but also securities market in the EU and the investment providers et al. This regulation clarifies reporting procedures and sets 
it to be more detailed and unified across EU Member States. It attempts to create more transparency in trading and for the investors, where in trading separating who has made the investment decision compared to who has made the execution decision; 4) Regulation No. 596/2014 also known as prevention of market abuse regulation. It targets to increase the investor protection against market manipulation and increase integrity of securities market, it is applicable to broader platform base compared to previous regulations and is updated to reflect recent changes in the investor and market related community behavior; 5) Finally, regulation No. 236/2012 or known as short selling regulation, because it is in general applicable to regulate dealings in short selling and credit default swaps. Intention is to provide more transparent pre-and post-trade data available to the public (investors) i.e., bid and offer prices and other information by the trading venues. Target is to reduce risk on uncovered short selling and settlement (Fig. 2).

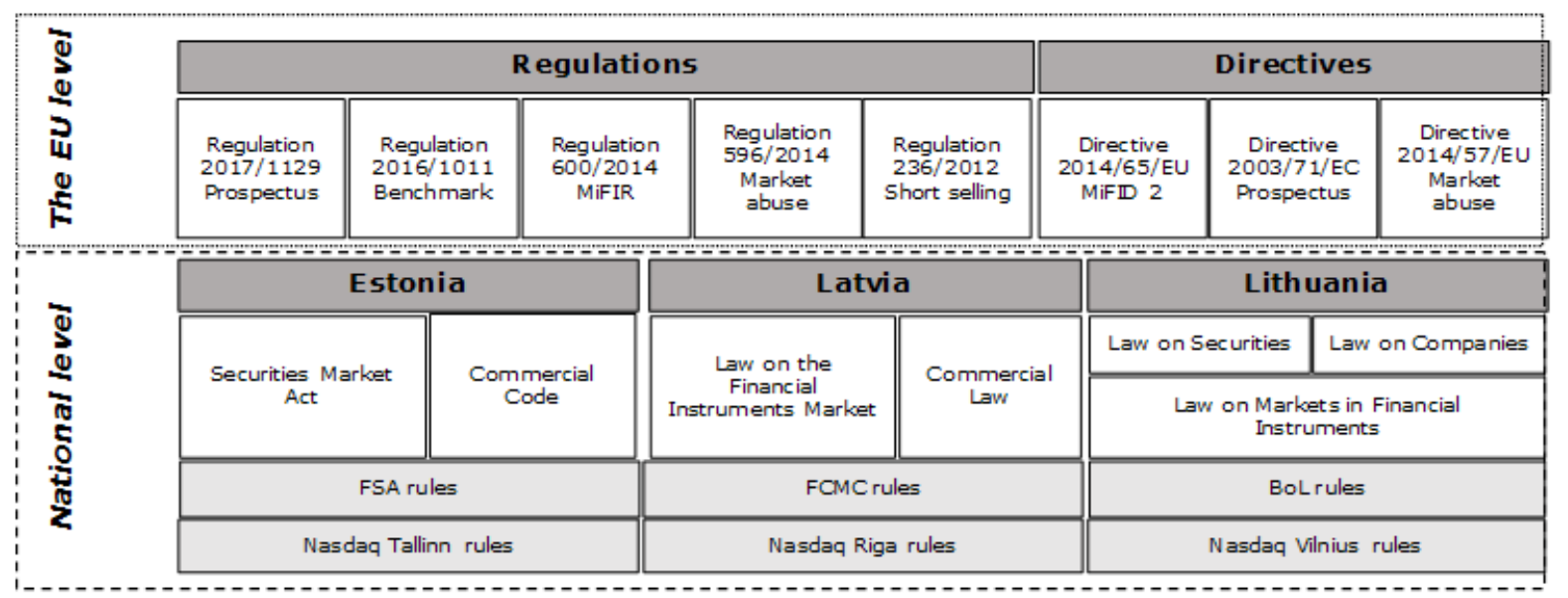

Source: Authors' constructed and derived based on ESMA, FSA, FCMC, Nasdaq Baltic, Regulation (EU) 2017/1129, Regulation (EU) 2016/1011, Regulation (EU) No 600/2014, Regulation (EU) No 596/2014, Regulation (EU) No 236/2012, Directive 2014/65/EU, Directive 2003/71/EC, Directive 2014/57/EU, Estonia: Securities Market Act, Estonia: Commercial Code, Latvia: Finanšu instrumentu tirgus likums, Latvia: Komerclikums, Lithuania: Law on Securities, Lithuania: Law on Companies, Lithuania: Law on Markets in Financial Instruments, Nasdaq Baltic rules and regulation for Tallinn, Nasdaq Baltic rules and regulation for Riga, Nasdaq Baltic rules and regulation for Vilnius.

Fig. 2. The Main EU and National Regulatory Framework of Stock Market in the Baltic States as of 01.01.2019.

Authors have identified three main existing directives (Fig. 2), which are in force as of 01.01.2019, with most important being No. 2014/65/EU or know as Markets in Financial Instruments Directive 2 in short MiFID 2 (replacing MiFID or previous directive No (2004/39/EC)). It sets definition of terms and increases regulation of financial markets and improves investors' protection via more transparent pricing, especially splitting of commissions charged for the analyst research and trading, increase standards for the investment related products. Long in force directive is also known as Prospectus directive No. 2003/71/EC. It is crucial for the companies planning to raise capital via public offering or to be admitted to trading, as well as to all involved parties, who help with prospectus and to local supervisory body, since this directive sets single and uniform general requirements for prospectus drafting, content etc. It also establishes publishing and validity of prospectus rules. Its main target is to have uniform standards, so the prospectus can be easily passported to other EU countries. Despite fact that regulation No 2017/1129 is repealing this directive, it is still in force. Third directive is No. 2014/57/EU to reduce market abuse. Both MiFID II/MiFIR are applicable only from 3 January 2018 according to ESMA.

Authors conclude that with changing investor and market behavior, the EU focus is now towards reducing market abuse (recent new regulation and directive) and setting uniform and more 
transparent standards and requirements for the prospectuses and investment bank/brokerage pricing, deal execution and insider information handling.

National level legislation. A. Kein (1998) emphasized that „the capacity and incentive of institutional investors to exercise ownership rights and intervene in portfolio-companies' management, is largely determined by the existing legal framework", and since the EU level legislation is unified across Member States, then role of national legislation is crucial and can make stock market attractive. There are two main impacting state laws in Estonia and in Latvia, while three in Lithuania. All companies must be first registered in commercial register as Joint Stock Companies (JSC) or in the process before listing converted to JSC. Only JSC shares can be listed, this is common rule among all three Baltic States. Commercial Code or Law on the Companies is the main company setting up and share issue regulating state level act in all three Baltic States (terms used slightly differs: Public Limited Company: AS in Estonia, Stock Company: AS in Latvia, Public Liability Company: AB in Lithuania). Authors are using term JSC as a form describing this type of companies, which is or can be listed.

Common company related rules among all three Baltic States are following:

1) Setting legal form of company as JSC, requirements of establishing, board, articles of association, setting rights for preferential shares, employee shares and running the company;

2) Setting number of management and supervisory board members;

3) Prohibition to acquire own shares, with few specific exceptions (Fig. 2).

Authors considers that there are two main most important differences for company formation and capital increase in the Baltic States law: 1) Different minimum amount of nominal share capital required for public JSC. The smallest is EUR 25000 in Estonia, EUR 35000 in Latvia, while the highest required is in Lithuania - EUR 40000; 2) Possibility of conditional share capital increase registration is only in Estonia, this usually speeds up process for investors after company has done the initial public offering (IPO) or secondary offering, to have new shares traded sooner.

Authors conclude that in Estonia the main law already sets it apart based on the least requirements for JSC, and in case of becoming solely listed or via the IPO route, it has the fastest bureaucratical route to start of trading due to possibility of the conditional share capital increase.

Second main state law is Securities Market Act (SMA) in Estonia, Law on the Financial Instruments Market (LFIM) in Latvia and Law on Securities (LoS) in Lithuania. These laws deal with setting rules and regulation in respect to dealing, issuing and trading of various securities, which the company can have.

Authors concluded that the most important features for stock issuers and investors are three clauses:

1. Setting in all countries when an offering is not qualified as public, main aspects are applicable if the offering is directed to solely qualified investors, or an offer addressed to fewer than 150 nonqualified investors per contracting country, or nominal value of one stock is equal or larger than 100000 EUR. This is important, since then there is No need to make prospectus and offering public, thus significantly reducing the costs of the capital raising or listing process.

2. They set in all three countries rules, when listed companies' major shareholders are gaining controlling authority, and when they can express voluntary takeover bid, or when they are obliged to express mandatory takeover bid to the minority shareholders. This part also sets the price calculation mechanism for mandatory takeover bid price per offer share, thus serves as a protection of minority shareholders of the listed company. 
3. And setting the criteria for qualifying as a small or medium company, it is also exactly stated in the prospectus regulation (must fulfill two out of three criteria, net turnover does not exceed EUR 50 million, average number of employees below 250, total assets below EUR 43 million). This is helpful when in the course of the offering if the company qualifies, they must fulfill minimum requirements set in the prospective directive and regulation, rather than the full set. Thus, it is less costly. According to the European Commission (2019): "small and medium-sized enterprises (SMEs) represent 99 \% of all businesses in the EU."

In Lithuania Law on Markets in Financial Instruments addresses mainly supervisory set up and financial brokerage firm organization and operation, thus has less impact on listed companies. From listed company perspective in Lithuania there are two main legal acts: Law on Companies and Law on Securities, as authors discussed above.

Lower significance though important are supervisory institution issued rules and regulations in each country. Market supervisory rules are the main rules of supervision, set mainly for banks and for fund managers, rather than specific rules for the issuers and investors. Specific rules for the issuers and investors are issued by market organizer Nasdaq, as is discussed below.

Market organizer rules and regulations. The EU and national legislation set high level requirements for the companies, while market organizer specifies in detail how and what a company must do to become listed and maintain the status of a listed company. In early 90-ties, while stock market in the Baltic States was only in the process of formation, it transitioned from unregulated and spontaneous stock market to regulated market with clearly set expectations and rules to follow by the market organizer. Market organizer Nasdaq Baltic has issued rules and regulations for each of three Baltic States. They set listing requirements and explain the process and requirements of listing as well as the organization of Nasdaq competent authorities, and process in case there is a breach of rules. Additionally, it sets out trading and settlement procedures and required disclosures by the issuers (Table 1). Authors discovered that Nasdaq Vilnius listing rules are available only in Lithuanian, thus stock market in Lithuania is at disadvantage compared to stock market in Latvia and in Estonia.

Table 1

Listing Requirements for the Issuers on the Baltic Stock Exchange Lists as of 01.01.2019.

\begin{tabular}{|c|c|c|c|}
\hline \multirow[b]{2}{*}{ Indicators } & \multicolumn{2}{|c|}{ The EU Regulated Market } & \multirow{2}{*}{$\begin{array}{c}\text { Alternative Market } \\
\begin{array}{c}\text { Baltic Alternative First } \\
\text { North }\end{array}\end{array}$} \\
\hline & Baltic Main List & $\begin{array}{l}\text { Baltic Secondary } \\
\text { List }\end{array}$ & \\
\hline $\begin{array}{l}\text { Market } \\
\text { capitalization/ } \\
\text { equity value }\end{array}$ & $\begin{array}{l}\text { Market value of shares should } \\
\text { be equal or above EUR } 4 \\
\text { million*. }\end{array}$ & At least EUR 1 million. & Not required. \\
\hline Free-float & $\begin{array}{l}\text { At least } 25 \% \text { of shares } \\
\text { belonging to public*. }\end{array}$ & $\begin{array}{l}\text { Enough shares } \\
\text { belonging to the } \\
\text { public. }\end{array}$ & Not required. \\
\hline $\begin{array}{l}\text { History of } \\
\text { performance }\end{array}$ & $\begin{array}{l}\text { Last } 3 \text { years annual audited } \\
\text { reports according to } \\
\text { international financial reporting } \\
\text { standards (IFRS). }\end{array}$ & $\begin{array}{l}\text { Last } 2 \text { years annual } \\
\text { audited reports } \\
\text { prepared according to } \\
\text { IFRS. }\end{array}$ & $\begin{array}{l}\text { Last } 2 \text { years annual audited } \\
\text { reports prepared according to } \\
\text { local accounting principles or } \\
\text { IFRS. }\end{array}$ \\
\hline Prospectus & Prospectus. & Prospectus. & $\begin{array}{l}\text { Prospectus or company } \\
\text { description prepared with CA. }\end{array}$ \\
\hline $\begin{array}{l}\text { Certified } \\
\text { Adviser (CA) }\end{array}$ & \multicolumn{2}{|l|}{ Not required. } & An agreement with CA. \\
\hline Ownership & \multicolumn{3}{|c|}{ Disclosure of shareholder ownership above $5 \%$. } \\
\hline
\end{tabular}

In the Baltic States there are three lists where the companies can get listed (Table 1). Baltic Main List and Baltic Secondary List - both are the EU Regulated Market, while third list: Baltic Alternative 
First North is an Alternative Market, it is not considered as regulated market per se, however, Nasdaq and supervisory institutions do regulate and supervise it, thus it has some attributes of the regulated market, though with less strict requirements. Smaller companies or companies, which do not meet or prefer not to follow the strict requirements of the regulated market, can get listed on the alternative market and get access to the investors. Long term institutional investors had preference for larger stocks, while recently it is changing, according to M.E. Blume and D.B. Keim (2012) state „that institutions have gradually increased their holdings of smaller stocks and decreased their holdings of larger stocks relative to market weights". Baltic Main List has the strictest requirements for admission to listing and requires company to be larger in size, though companies in Baltic in general are SME, which is micro companies when compared to the ones listed on the stock markets in the Europe or USA. Requirements for being listed on the Baltic Secondary List is lower and thus these shares present higher degree of risk than shares listed on the Baltic Main List according to Nasdaq. Existence of three lists, allows the issuers and investors to choose the most appropriate one meeting their needs and requirements. For shares to be considered for listing, they need to be freely transferable and in addition to company being JSC, the shares must be registered with the depository. Once company becomes listed, each of the lists set reporting and disclosure requirements for the issuers (Table 2). The least requirements are for the companies listed on Baltic Alternative First North list.

Table 2

The Main Reporting and Disclosure Requirements for the Listed Companies on Stock Market in the Baltic States as of 01.01.2019.

\begin{tabular}{|c|c|c|c|}
\hline \multirow[b]{2}{*}{ Indicators } & \multicolumn{2}{|c|}{ Regulated Market } & \multirow{2}{*}{$\begin{array}{c}\text { Alternative Market } \\
\text { Baltic Alternative First North }\end{array}$} \\
\hline & Baltic Main List & $\begin{array}{l}\text { Baltic Secondary } \\
\text { List }\end{array}$ & \\
\hline Financial reports & \multicolumn{2}{|c|}{$\begin{array}{l}\text { Audited annual report and interim reports of } 3, \\
6,9 \text { and } 12 \text { months. }\end{array}$} & $\begin{array}{l}\text { Audited annual report and } 6 \text { months } \\
\text { interim report. }\end{array}$ \\
\hline $\begin{array}{l}\text { Disclosure } \\
\text { requirement }\end{array}$ & \multicolumn{3}{|c|}{$\begin{array}{l}\text { Any economic or significant information of the issuer or its subsidiary if it is No less } \\
\text { than } 10 \% \text { of the issuer. }\end{array}$} \\
\hline $\begin{array}{l}\text { Corporate } \\
\text { governance code }\end{array}$ & \multicolumn{2}{|c|}{ The issuer must inform if it complies or not. } & Not required. \\
\hline \multirow{4}{*}{ Other } & \multicolumn{2}{|c|}{$\begin{array}{l}\text { Number of shares owned by management and } \\
\text { supervisory board and their connected persons. }\end{array}$} & $\begin{array}{l}\text { Number of shares owned by } \\
\text { management and supervisory } \\
\text { board, CA and their connected } \\
\text { persons. }\end{array}$ \\
\hline & \multicolumn{2}{|c|}{$\begin{array}{l}\text { Information on share transaction performed by } \\
\text { persons of or linked to the issuer. }\end{array}$} & \multirow{2}{*}{$\begin{array}{l}\text { Report significant transactions } \\
\text { above } 10 \% \text { of the issuer's share } \\
\text { capital. }\end{array}$} \\
\hline & \multicolumn{2}{|c|}{$\begin{array}{l}\text { Trade and price statistics for the reporting } \\
\text { period. }\end{array}$} & \\
\hline & \multicolumn{3}{|c|}{$\begin{array}{l}\text { Decision of share capital increase/decrease or dividend payment, any share related } \\
\text { action. }\end{array}$} \\
\hline
\end{tabular}

Source: Authors' constructed and derived based on Nasdaq rules and regulations in the Baltic States.

\section{Conclusions, proposals, recommendations}

1) The institutional organization for stock market in the Baltic States is rather similar, with exception that in Estonia and Latvia, there is a separate organization, which performs supervisory duties, while in Lithuania these functions are delegated to the Bank of Lithuania.

2) National laws have two main differences across the Baltic States, one is for setting the minimum nominal value required for setting up JSC, where in Estonia this requirement is the lowest, and in Lithuania it is the highest. Other difference is that in Estonia it is possible to have conditional capital increase, which speeds up the trading process of new shares, while in Latvia and in Lithuania, it is not possible. 
3) Despite having a unified and known as the Baltic stock market, the issuers need to get registered and follow local stock market rules and regulations issued by three market organizers: Nasdaq Tallinn, Riga and Vilnius, where in last, listing rules for stock market is only in Lithuanian. Authors recommend to consider on the market organization level to have one common legal entity instead of three. It needs to be further investigated what are the obstacles to have that and whether benefits outweigh costs and risks.

\section{Acknowledgment:}

The research was supported by the National Research Programme "Latvian Heritage and Future Challenges for the Sustainability of the State" project "Challenges for the Latvian State and Society and the Solutions in International Context (INTERFRAME-LV)"

\section{Bibliography}

1. Baltic States to create a pan-Baltic capital market (2017). Retrieved: https://www.ebrd.com/news/2017/baltic-states-to-create-a-panbaltic-capital-market.html. Access: 31.01.2019.

2. Bank of Lithuania. Retrieved: https://www.lb.It/en/. Access: 31.01.2019.

3. Blume, M.E., Keim, D.B. (2012). Institutional Investors and Stock Market Liquidity: Trends and Relationships, Retrieved: http://finance.wharton.upenn.edu/ keim/research/ChangingInstitutionPreferences_21Aug2012.pdf. Access: 01.02.2019.

4. Boubakari, A., Jin, D. (2010). The Role of Stock Market Development in Economic Growth: Evidence from Some Euronext Countries. International Journal of Financial Research, Vol. 1, No. 1, pp 14-20.

5. Brousseau, E., Nicita, A. (2010). How to design institutional frameworks for markets. Revue d'économie industrielle, Retrieved: http://journals.openedition.org/rei/4144; DOI: 10.4000/rei.4144 pp. 87-118. Access: 30.01.2019.

6. Deltuvaitè, V. (2016). Investigation of Stock Market Integration in the Baltic Countries. Economics and Business, vol. 28, issue 1 , pp. 38-44. Retrieved: https://content.sciendo.com/view/journals/eb/28/1/article-p38.xml. Access: 29.01.2019.

7. Directive 2003/71/EC of the European Parliament and of the Council of 4 November 2003 on the prospectus to be published when securities are offered to the public or admitted to trading and amending Directive 2001/34/EC. Retrieved: https://eur-lex.europa.eu/legal-content/EN/TXT/?uri=CELEX \%3A32003L0071. Access: 03.01.2019.

8. Directive 2014/57/EU of the European Parliament and of the Council of 16 April 2014 on criminal sanctions for market abuse. Retrieved: https://eur-lex.europa.eu/legalcontent/EN/TXT/?uri=CELEX \%3A32014L0057. Access: 10.01.2019.

9. Directive 2014/65/EU of the European Parliament and of the Council of 15 May 2014 on markets in financial instruments and amending Directive 2002/92/EC and Directive 2011/61/EU. Retrieved: https://eurlex.europa.eu/legal-content/EN/TXT/?uri=celex \%3A32014L0065. Access: 19.01.2019.

10. Estonia: Commercial Code. Retrieved: https://www.riigiteataja.ee/en/eli/504042014002/consolide. Access: 19.01.2019.

11. Estonia: Securities Market Act. Retrieved: https://www.riigiteataja.ee/en/compare_original?id=517012019004. Access: 01.02.2019.

12. European Commission. Retrieved: http://ec.europa.eu/growth/smes/business-friendly-environment/smedefinition_en. Access: 30.01.2019.

13. European Securities and Markets Authority, supervisory framework. Retrieved: https://www.esma.europa.eu/about-esma/governance/european-supervisory-framework. Access: 17.01.2019.

14. Financial and Capital Market Commission. Retrieved: http://www.fktk.lv/en/. Access: 31.01.2019.

15. Financial Supervision Authority. Retrieved: https://www.fi.ee/en. Access: 31.01.2019.

16. Hogson, G.M. (1998). The Approach of Institutional Economics. Journal of Economic Literature, pp. 166-192.

17. Kein, A. (1998). Development of Capital Markets and its Institutions in Estonia. Retrieved: https://www.nato.int/acad/fellow/96-98/kein.pdf. Access: 28.01.2019.

18. Lannoo, K. (2001). EU Securities Market Regulation Adapting to the Needs of a Single Capital Market. Report of a CEPS Task Force, Centre for European Policy Studies, pp. 1-61.

19. Latvia: Finanšu instrumentu tirgus likums (Law on Financial Instruments Market). Retrieved: https://likumi.Iv/doc.php?id=81995. Access: 07.09.2018.

20. Latvia: Komerclikums (Commercial Law). Retrieved: https://likumi.lv/doc.php?id=5490. Access: 07.09.2018.

21. Levine, R. (1991), Stock Markets, Growth, and Tax Policy. The Journal of Finance, Vol.46, issue 4.

22. Lithuania: Law on Companies. Retrieved: https://www.lb.It/en/legislation. Access: 12.01.2019. 
23. Lithuania: Law on Markets in Financial Instruments. Retrieved: https://www.lb.It/en/legislation. Access: 12.01.2019.

24. Lithuania: Law on Securities. Retrieved: https://www.lb.lt/en/legislation. Access: 12.01.2019.

25. Nasdaq Baltic rules and regulation for Riga. Retrieved: https://nasdaqbaltic.com/en/our-services/rules-andregulations/nasdaq-riga/. Access: 20.01.2019.

26. Nasdaq Baltic rules and regulation for Tallinn. Retrieved: https://nasdaqbaltic.com/en/our-services/rulesand-regulations/nasdaq-tallinn/. Accessed 19.01.2019.

27. Nasdaq Baltic rules and regulation for Vilnius. Retrieved: https://nasdaqbaltic.com/en/our-services/rulesand-regulations/nasdaq-vilnius/. Access: 21.01.2019.

28. Nasdaq Baltic. Retrieved: https://nasdaqbaltic.com/en/about-us/nasdaq-baltic/. Access: 18.01.2019.

29. Nasdaq CSD. Retrieved: https://www.nasdaqcsd.com/. Access: 03.02.2019.

30. Regulation (EU) 2016/1011 of the European Parliament and of the Council of 8 June 2016 on indices used as benchmarks in financial instruments and financial contracts or to measure the performance of investment funds and amending Directives 2008/48/EC and 2014/17/EU and Regulation (EU) No 596/2014. Retrieved: https://eur-lex.europa.eu/legal-content/EN/TXT/?uri=CELEX \%3A32016R1011. Access: 11.01.2019.

31. Regulation (EU) 2017/1129 of the European Parliament and of the Council of 14 June 2017 on the prospectus to be published when securities are offered to the public or admitted to trading on a regulated market, and repealing Directive 2003/71/EC. Retrieved: https://eur-lex.europa.eu/legalcontent/EN/TXT/?uri=CELEX \%3A32017R1129. Access: 04.01.2019.

32. Regulation (EU) No 236/2012 of the European Parliament and of the Council of 14 March 2012 on short selling and certain aspects of credit default swaps. Retrieved: https://eur-lex.europa.eu/legalcontent/EN/TXT/?uri=celex \%3A32012R0236. Access: 03.01.2019.

33. Regulation (EU) No 596/2014 of the European Parliament and of the Council of 16 April 2014 on market abuse (market abuse regulation) and repealing Directive 2003/6/EC of the European Parliament and of the Council and Commission Directives 2003/124/EC, 2003/125/EC and 2004/72/EC. Retrieved: https://eurlex.europa.eu/legal-content/EN/TXT/?uri=CELEX \%3A32014R0596. Access: 10.01.2019.

34. Regulation (EU) No 600/2014 of the European Parliament and of the Council of 15 May 2014 on markets in financial instruments and amending Regulation (EU) No 648/2012. Retrieved: https://eurlex.europa.eu/legal-content/EN/TXT/?uri=CELEX \%3A32014R0600. Access: 04.10.2018.

35. Rupeika-Apoga, A. (2013). Financial Markets in the Baltic States in the Changing Environment. Conference proceedings New Challenges of Economic and Business Development.

36. The European Union legal acts. Retrieved: https://europa.eu/european-union/eu-law/legal-acts_en. Access: 17.01.2019. 